\title{
Jesus and Afro-Pentecostal prophets: Dynamics within the liminal space in Galilee and in Zimbabwe
}

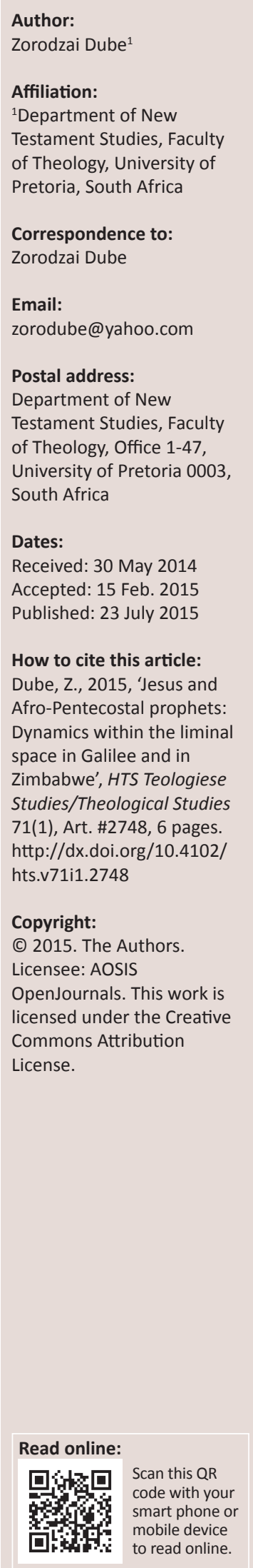

What happens when religious and spiritual interventions are used to explain concrete social economic reality? This study suggests that Afro-Pentecostal prophets in Zimbabwe exist within the liminal context; the prophets therefore function to redefine and contest identities in view of present social realities. This realisation allows for a comparison between the Zimbabwean prophets and Jesus of Nazareth, with a view to draw general conclusions regarding the function of prophets. As contribution, the study fills the void within the studies concerning the religious explanations of socioeconomic issues in view of structures of power. Borrowing from Herbert Marcuse, this study advances the thesis that the prophets attract people by miracles and promises of bliss and, in the process, divert people's attention from directly confronting structures of power and hegemony.

\section{Introduction}

This study develops from the observation that a 'mushrooming' effect exists in terms of the presence of Zimbabwean prophets because of the rise in economic hardship - especially within the Afro-Pentecostal and evangelical tradition. The prophets and religious seers claim a panoptic insight based on divine power, which enables them to predict events in the immediate future and many other issues related to personal problems. In the absence of a functioning economy and health sector in Zimbabwe, the prophets seem to provide an alternative space within which religious canopies are used to explain socioeconomic issues. Based on this observation, the underpinning research question examines how we understand the religious explanation of economic and political issues by the prophets in view of structures of power. Do prophets and seers provide a positive role or do they pacify and divert people's attention and entrench oppression in the process? The social context under which prophets operate in Zimbabwe will be discussed; this argument will provide a comparative platform upon which to infer the role of Jesus during 1st century Galilee.

\section{Zimbabwean context and the rise of religious prophets}

In explaining capitalism as a mutating and oppressive structure, Herbert Marcuse (1897-1979) (1955:10) criticised the media and the advertising industry for dangling erotic images in print campaigns that divert people's attention from the oppression due to capitalism. Marcuse's critique of the media may provide a platform to critique what seem to be a diversion due to the Zimbabwean prophets who promise people houses, jobs, money and cars, thus giving illusion to the people that their economic challenges have been solved through spiritual means. To understand this critique, I shall provide background to issues in Zimbabwe. During the botched land reform programme that took place from 2000 onwards, the Zimbabwean economy responded by declining rapidly. Within a few months, the impact of the ill-timed political decision was evident in the economy as basic commodities disappeared from shops. The Zimbabwean dollar lost its value against international currencies and the country was gripped by unprecedented levels of poverty. As a result, the middle class, including artisans and civil servants, migrated to neighbouring countries where they could market their labour. It seem due to these economic challenges, a void was created in terms of the public service sector, schools and hospitals lacked skilled personnel.

The coincidence in terms of the mushrooming of Afro-Pentecostal prophets during such critical times is of interest to this study. In the absence of a functioning health sector and economy, the prophets, mostly from an Afro-Pentecostal tradition, promised people instant healing and economic prosperity. Seemingly, the prophets came at the right time because they talked about the issues that people wanted to hear about. Studies by Tabona Shoko (2013:217) suggest comparison between the Afro-Pentecostal prophets with traditional healers, thus seeing the emergence of Pentecostal prophets as typifying the contextualisation of African spiritualties. Shoko's position, which supposes a link between the rise of prophets and traditional healers, draws from an anthropological and phenomenological viewpoint. Unlike Shoko, I take a critical 
stance whereby I evaluate the function of the prophets in terms of their positive role in addressing the socio-economic challenges within the country. When the prophets promise people miracle money, miracle healing and other promises, are they helping or are they creating an alternative imagery space to socio-political matters. It seems their involvement spiritualises issues that need real solutions. Typical examples include Prophet Emmanuel Makandiwa and Prophet Eubert Engels who claimed that they possessed the ability to perform supernatural miracles, such as resurrecting the dead, putting 'miracle money' into people's pockets, making possible 'miracle pregnancies' that would help barren women, predicting job opportunities for job seekers, giving prophecies regarding a spouse, a car, or a house. Prophet Eubert Engel, ${ }^{1}$ during a radio interview, claimed to have resurrected 29 people (Nehanda Radio 2013). If true, he would have put the undertakers out of business! In addition, Engel claimed that he possessed the ability to create 'miracle money', which he only stopped after the governor of the Reserve Bank of Zimbabwe, Gideon Gono, reprimanded and threatened him with criminal charges for injecting cash liquidity in the market, thus destabilising the economy. Besides Zimbabwe, other African countries such as Nigeria boast of the services of Prophet T.B. Joshua (2014), allegedly poignantly predicted the recent disappearance of the Malaysian aeroplane, as well as the deaths of public figures such as Nelson Mandela and Malawi's Bingu WaMutarika.

The people's reaction towards the miracles is mixed, with some people defending the activities as the proof for divine power, whilst others accuse the prophets of using muti or magic. One such typical public mistrust is expressed in an online article, The art of clerical charlatanism (Sekuru Nhova 2014, 28 March). The author negatively labelled the prophets as 'spiritual charlatans' or 'gospreneurs', castigating the prophets for living a 'bling' lifestyle, and possessing vast riches that include the latest luxury cars and cosy houses - a lifestyle similar to American hip-pop musicians. However, in the absence of a functioning economy and an effective health sector, the Zimbabwean people have found an immediate alternative in the form of the 'men of God' who seem more than enthusiastic to provide solutions to any vexing social issues.

My approach, which is inspired by Herbert Marcuse, combines ideas from Victor Turner to propose that the prophets arise within a liminal space to divert people's attention from real questions of existence. Do the prophets help or are they an obstruction? Does their religious therapy to socioeconomic questions prove useful? Answers and discussions to this study shall be used to draw parallel with Jesus of Nazareth regarding the context and function of prophets.

I must stress that the comparison with Jesus is limited to context and function; it is not about the personality of Jesus and the Zimbabwean prophets. Comparatively, Jesus of 1.African Pentecostalism is a new brand of Christianity, distinct from classical
Pentecostalism. For instance, it borrows heavily from African worldviews and spiritualities (cf. Kalu 2005).
Nazareth operated within a politically and economically tense environment (Freyne 2000:86). An economic boom associated with the reign of Tiberius resulted in prosperity in Galilee and the surrounding regions. However, the prosperity in agriculture and trade was controlled and usurped by the Roman Empire, leaving the peasants with little to subsist. The extent to which the Empire was physically present in Palestine is debatable, but it is an undisputable fact that Roman representatives who were stationed in Caesarea and Sipphoris and other imperial cities, reinforced the imperial interests (Freyne 2000:86). Thus, Jesus of Nazareth, the messiah claimant (Reed 1999:87), functioned within a liminal context where the people suffocated under imperial control. Plausibly, the asymmetric feudal context from which Jesus operated and his performance of miracles, evokes similar questions posed concerning the prophets in Zimbabwe.

\section{Theory: Locating a liminal space}

This study adopts the theoretical perspective that people adopt religion as a functional worldview to provide a balance within a liminal or challenging situation. From this perspective, plausibly, the belief in prophets and messiah presupposes a certain worldview; a certain ordering and a belief that there are supernatural powers that directly influence daily events. From Aristotle's time (Ackrill \& Judson 1993:31), with his views regarding the 'prime mover' to scholastic thinkers, such as Thomas Aquinas, the existence and the direct influence of supernatural powers over the affairs of humankind have been uncritically accepted. Even idealistic thinkers such as Leibniz, Descartes and Spinoza, in emphasising the soul as the primary link to the metaphysical powers, attributed good morality to the existence of the Supreme Being (Veitch 1960:12). Such an enchanted worldview would interpret miracles as the once off visit by the gods (or God) into the affairs of humanity. Such an approach to life is predicated on the idea that people are infinite and that there is a stronger and omniscient being seated somewhere and directing history.

Generally, most African cultures share this worldview (Shoko 2007:2). Buoyed in such a worldview and fearing that by criticising metaphysical powers they would evoke retaliation from the gods or God, most African societies do not take a critical stance towards miracles or anything that involve the spiritual powers. Studies by Rudolf Bultmann (1958:7) and David Strauss (1972:5) make it possible to postulate that the Ancient Mediterranean worldview share similar characteristics; a worldview whereby spiritual beings were believed to directly interact with humans. For example, the people within the Ancient Mediterranean culture believed that illness was an alarm that signified a negative disposition towards the spiritual world and that good health and riches were a testimony of good favour from the gods (Malina 1996:67).

On the other hand, the enlightenment and rational thinkers put emphasis on the individual's ability to solve one's own personal problems without the external help of the gods. 
For example, the France phenomenologist, Jean Paul Sartre (1992:20) dismissed the existence of the gods, stating that the absence of the creator makes humans absolutely free, as there is no essence prior to birth. For Sartre, people are accountable and responsible for their own actions. Implicitly, one can hear Sartre's indebtedness to Nietzsche (1967:18) who protested against any form of authority, be it from church or society. Nietzsche argues that people must have freedom to follow their 'inner law' and not being coerced to comply with ethics and Christian morality. ${ }^{2}$ Metaphorically, Nietzsche is famous in proclaiming the death of God, symbolising the end of false consciousness, which he calls nihilism. He accused Christianity of adopting a slave morality of pity and humility; instead of allowing people to follow their individual talents of valour, greatness and heroism (Nietzsche 1967:185). To avoid Nietzsche's nihilism, people must break-off from their slave mentality and accept their individualism and creativity (Nietzsche 1967:185)

Important to this study is the idea that the manner in which people rationalise about the gods is exponentially related to their social problems. Plausibly, in cultures where people cannot overcome their problems or have given-up hope in solving them, the existence of the gods becomes an unquestionable reality. In Algeria during France colonialism, Frantz Fanon (1963:55) noted that there was a link between the local people's belief in spirit possession and their situation of colonialism. People who face surmountable life challenges surrender their responsibility of solving them to the gods, thus creating an external and more powerful being that can face the external problems. To such people, the gods engage in spiritual contest with unseen spiritual beings such as the angels, demons and other evil gods. This means that, if people accept the responsibility to solve their own social problems, then people become creative and active in directing their own destinies (Bourdieu 1977:20), they are not hopeless under structures of power, whether seen or unseen (Foucault 1977:35).

Theoretically, the belief in the gods may be explained as an indication of a quest for normalcy, a need to exit the liminal space. The concept of liminality from the anthropologists (Victor Turner \& Edith Turner 1978:21) and Arnold van Gennep (1969:5) explains that a volatile economic and political situation is a transitory space, a precarious position; a point of tension, of unfixed identities; of uncertainty and a point of crisis. Being helpless under such a situation is likely to make the belief in the gods plausible. Turner and Van Gennep talk of the liminal space from the perspective of rituals and, I borrow the same concept to locate the context from which prophets and seers operate. Ritually, liminal people would have exited the previous social group, but have not yet been accepted into the next stage, thus they are in the middle a place of nowhere. Words that characterise a liminal place are volatility, transitory and/or unpredictability (Turner \& Turner 1978:21). Similar words can be used to describe the situation of people within a politically and economically volatile context. Arnold van Gennep (1969:5) explains that the most important practitioner within the liminal space is the ritual leader who provides rituals of transition, or creating a normative communitas, an alternative community where the people can redefine their own identity separate from the rest. Comparatively, the ritual leader may be seen in the same light as the function performed by the prophets in Zimbabwe and Jesus of Nazareth, which is providing spiritual insights to their problems.

\section{Comparative discussion: Creating a liminal communitas in Zimbabwe and in Galilee}

If prophets exist within a liminal situation where the people yearn to exit, do the prophets help or do they divert people's attention from the real issues? I take Herbert Marcuse's perspective to argue that the prophets dangle miracles and the promises of a better life, which divert people's attention from confronting structures of power. Prophets make people hide in a supernatural makeshift worldview. The following are important comparative aspects of how the prophets function within a liminal space.

Firstly, the prophets spiritualise the material; they reverse the normal perception of things. Instead of confronting the physical hegemony, they focus on the spiritual realm, thus, instead of taking action against the real oppressor, people pray, fast and wait for gods to do the rest. In Zimbabwe, the church for the past 10 years must be given credit for pacifying people from being politically active. Instead of demonstrating and sloganeering against Mugabe, the church encouraged people to fast and to pray. In many of their assemblies, the prophets and preachers redefine power dynamics; power is not a physical confrontation against Mugabe, but in prayer. I have already alluded to Nietzsche, during the 19th century, who accuses the ethics of the church as nihilism, which is, reversing the normal virtues of power, fortitude, and masculinity as evil. Instead, Christians must be meek, humble and obedient - which Nietzsche (1967:185) describes as slave traits. In Zimbabwe, one prophet posed the question (Sibiya 2013), 'Why am I poor even though I am a Christian?' According to this prophet (Sibiya 2013), people are poor because they do not tithe; he cautioned that people must check for signs of demonic possession. In this regard, tithing is understood as seeding or depositing to God with an expectation for cash withdrawal. Thus, a monetary transaction that does not happen in the real world because of the failed economy is now given a spiritual perspective. Instead of viewing poverty as a structural issue, it is given a spiritual dimension. Marx Weber (1930:13) says the church, especially the protestant theology, blames the victim by telling the poor to work harder, even if they do not experience the fruits of their labour. Demanding moral and spiritual purity from the economically oppressed people is avoiding the real economical questions and the concomitant inequalities within the society. 
Is there any benefit in hiding in the spiritual realm? Why do the prophets spiritualise the material issues? From an identity perspective, when people cannot attain what they yearn for, they create another social canopy to redefine social order, which becomes their own standard of social competition. As an example, James Muzondidya (2010:37) studied identity competition between the Zimbabweans who are in South Africa and the local people. The local South Africans look down upon the Zimbabweans as immigrants, and in exchange, the Zimbabwean people redefine their identity as so-called better people who are more educated, wiser, more enlightened, and more civilised than the South African locals who riot and burn public property. This means that people compensate what they cannot attain by appealing to an improved identity category in an attempt to outwit their opponent.

If true, the prophets in Zimbabwe, in view of the liminal space, acknowledge the futility of confronting the armed and ready-to-pounce Zimbabwean army, thus they create another avenue to contest power and privilege. In this case, instead of fighting for their economic share and political freedom, power is seen as keeping silent, as being more prayerful. Keeping the peace and not fighting are regarded as being more humane compared to the violent politicians. From this perspective, prayer to God replaces civil rights. The political leaders are brushed aside as less-than providers; therefore, the best provider is God, who listens and provides better.

Did Jesus spiritualise the real issues? Did he reverse the noble virtues of a feudal society? It must be noted that what we know about Jesus is embellished in the memory of the early church and was retrieved and deployed in oral form as an ethical standard by the various early Christian communities. In fostering community peace between the Hellenistic Jews and the Orthodox Jews, Matthew remembered Jesus as a person of peace. In Matthew 5-7, known as Jesus' Sermon on the Mount, Jesus admonished his followers to forgive and to practice peace as a hallmark of community identity. In emphasising this, Jesus said, 'do not resist one who is evil, but if any one strikes you on the right cheek turn to him the other one' (Mt 5:38). The reason for not resisting evil and for practicing peace is that the heavenly father knows his own and will judge the wicked in the eschaton. In Luke, Jesus is portrayed as a martyr, an identity which the community must adopt in the manner they suffer on behalf of the poor (Lk 10:6). Equally, at the heart of Mark's gospel is a rebuttal of what Mark calls an erroneous Christology, which is viewing Jesus as a political Messiah. Thus instead of the Markan Jesus to be remembered as a political Messiah, he is a suffering Messiah, nonaggressive and apolitical (Mk 8:31, 9:31-32).

It seems the Galilean Jesus avoided confrontation and he spiritualised political and economic issues. The Galilean communities knew about the brutality of the Empire and the futility of insurrection. Read from this perspective, it seems the early Christian communities, retold the story of Jesus from their context, as a story whose ethical teaching was about peace. In doing so, the narrative of Jesus subverted the celebrated hegemony and masculinities of the Empire by juxtaposing the feudal virtues with alternative identity categories of peace, hospitality and meekness. Thus, like the Afro-Pentecostal prophets, Jesus redefined the identity of his communities in a way that rivalled the dominant narrative.

Secondly in Zimbabwe, a powerful preacher casting out demons of hunger, poverty, barrenness and unemployment, a characteristic of being in a liminal space. In Zimbabwe, a powerful preacher is known for casting out demons of hunger, poverty, barrenness and unemployment. Therefore, banishing demons could be seen as socialmedical problems, which leads to the question whether demon possession should be regarded asocial. Fanon (1963:55), from a psychological perspective, indicates that demon possession is linked to the social context. Previously, I developed and contextualised this argument and argue that demon possession in Zimbabwe can be described as an indirect confrontation against structures of oppression (Dube 2012:352). Important to this study, is that the prophets identify the social issues confronting the people from a spiritual dimension. Instead of embarking on a direct confrontation with the government, which does not provide access to clinics and jobs, the accusation is internalised in the form of demonic possession. Psychologically, these selfblaming functions lead to avoiding direct confrontation with the oppressor, especially when the confrontation will result in further oppression. Plausibly, the prophets provide a psychological platform in terms of diverting attention from the oppressors to within, thus creating an alternative space whereby, instead of confronting the oppressor and demanding freedom, the people self-inflict and blame themselves. The exorcisms in Zimbabwe can be understood as rituals that exhibit the frustration and hopelessness amongst people, and their constant failure to overthrow Mugabe. Instead, the people turn upon themselves, blaming each other of being spiritually impure, which echo the view that a liminal stage is a place of frustration and anxiety (Arnold van Gennep 1969:5; Victor Turner \& Edith Turner 1978:22).

A comparative link can be drawn with Jesus of Nazareth. New Testament scholars have established that Jesus' exorcisms can be explained from the reality of the Roman Empire. Jesus' ministry coincided with the emperorship of Tiberius (14 CE - 37 CE) and Herod Antipas (6 CE - 39 CE), a puppet king in Galilee (Hanson \& Oakman 1998:135). Various scholars present two conflicting pictures of Galilee, with some like Jonathan Reed (1999:87), Eric Meyers (1981:5) and Douglas Edwards (1992:62), suggesting a peaceful and prosperous Galilee characterised by a booming trade and population. There is no doubt that, in Galilee, Emperor Tiberius's reign coincided with trade and prosperity. However, who benefited from the trade and prosperity? If the topic is discussed from the perspective of the Empire, emphasising the pax-Romana (peace), the conclusion is likely to result in a positive view of the Empire from which the early church indirectly benefited from the established 
cosmopolitanism and infrastructure. However, if looked from the perspective of the peasants, a perspective which Richard Horsley (1997:26) takes, then the picture is less appetising. The influence of the Empire resulted in usurpation of land and the establishment of commercial farms, which swathe peasants who have been removed from their ancestral lands. The celebrated Roman peace was guaranteed by violence and suppression, especially people categorised and labelled as deviant by the Empire (Peppard 2010:450).

The picture of prosperity changed during the second half of the 1st century, due to weak emperors like Gaius Caligula (37 CE - 41 CE) and Nero (54 CE - 68 CE). Many regions demanded their independence from the Empire, including the Jewish people. Several factors caused this tension. According to Sean Freyne (2000:27), the growing urbanisation created cultural and economic tension with the subsistent peasant life. Mostly, people who resided in cities such as Tiberius and Sipphoris were Roman equestrians, people of means, especially property owners. The emergence of landlords, whose purpose was to cultivate large pieces of land to feed the hungry aristocratic city dwellers in local cities and in Rome, meant the increasing demand for food through annexation of land from the peasants.

Why did Jesus cast out demons instead of direct confrontation with the Empire and the feudal lords? If understood from the perspective of liminality, plausibly, Jesus' exorcism, similar to Zimbabwe, created an illusion of power confrontation, thus diverting energy from the Empire to spiritual confrontation. Possibly, Jesus was aware of the reality of the Empire and the suicidal consequences of confronting the Empire. My view is that Jesus lived in a generation where people believed that physical actions have a spiritual response; thus, like any Jewish person, the inversion and the defeat caused by uncircumcised nations were interpreted from the lens of faith as punishment from the spiritual world. It is possible that Jesus genuinely believed that by casting out demons and through moral regeneration, Yahweh would recast his favour upon them.

Thirdly, the prophets promise prosperity, healing and a better future. What is the function, from a psychological perspective, of miracles? If explored from the perspective that miracles and healings happen within a liminal space, then miracles and healings create an illusion of wholeness. Again, Marcuse's (1955:10) criticism of capitalism is useful here. Marcuse criticised capitalism and especially the advertising industry for functioning as forms of social control by parading erotic images as erotic sublimation. The erotic advertisement gives the oppressed the illusion that they, too, share in the capitalistic project, yet in reality, they are being oppressed. Similarly, miracles and promises of instant prosperity by the prophets falsely make people think they have attained the material desires they wished for; yet in reality, it is mere empty promises. In Zimbabwe, the people need the economy to run smoothly again, their education system to be repaired, and their relatives who relocated to foreign countries to come back to a functioning economy and heath sector. Miracles, psychologically, give the false impression of normalcy, yet things are in shambles.

Comparatively, Jesus of Nazareth performed miracles, and scholars such as Bultmann (1958:36) viewed them as prescientific, typical of mythological worldviews. For Bultmann, within Jesus' prescientific worldview, miracles were used to explain the extraordinary events and, within such an enchanted worldview, the activities of the gods were witnessed on a daily basis. It is no surprise, therefore, that 1 st century Jewish people waited for the divine intervention of God through the appointed messiah. Miracles were regarded as proof of the messiah and they strengthened the belief that God shall act on behalf of the people. Plausibly, miracles, during the 1st century, attracted people from personally responding to the hegemony of the Empire to believing that Yahweh shall intervene.

\section{Conclusion}

The study locates the prophets as practitioners within a liminal space whose function is to provide a religious explanation in terms of socio-political issues. The study concludes that the religious explanation diverts the people's attention from the real issues and their ability to respond physically to hegemony. In terms of Zimbabwe, the prophets use miracles, healing and other material promises. A critical point can be raised concerning Africa and its democratic processes, that is, the religious canopy, which is used to explain economic and political issues, has resulted in leaders such as Mugabe prolonging their stay. In certain cases, a religious worldview could provide a fertile ground for dictatorship. It shuns confrontation with those in power; instead, it postpones and allocates action to the gods. On a positive side, a religious explanation can be seen as a strategy for survival in cases where confrontation is suicidal, thus brooding cowardice as a strategy for survival.

In the case of Jesus, I believe a sympathetic approach is called for, based on understanding the worldview construction of the people. Jesus believed that sin invites punishment from God and as a response, people must keep themselves morally upright. Like any 1st-century Jewish person, Jesus awaited the quick intervention of God to fight the Empire. Plausibly, Jesus was a prophet within a liminal space and he used miracles and healings to divert and squash insurrection. Instead of a direct confrontation with the Empire, Jesus taught his followers to be nonaggressive, peaceful, and to wait for God to intervene in their desperate situation. Like the Zimbabwean prophets, Jesus presented an imaginary world that decrypted the world of the Empire (Lefebvre 1991:39). Liminal places make people feel an in-between experience; a joint experience; a heterotopias (Foucault 1977:333), thus making them more vulnerable and hopeless.

\section{Acknowledgements}

The author would like to acknowledge the University of Pretoria for the funding of the research leading to the publication of this article. 


\section{Competing interests}

The author declares that he has no financial or personal relationships, which may have inappropriately influenced him in writing this article.

\section{References}

Ackrill, J.L. \& Judson, L. (eds.), 1993, Aristotle aposterior analytics, Oxford University Press, New York, NY.

Bourdieu, P., 1977, Outline of a theory of practice, Cambridge University Press, Cambridge. http://dx.doi.org/10.1017/CBO9780511812507

Bultmann, R., 1958, Jesus Christ and mythology, Charles Scribner's Sons, New York, NY.

Dube, Z., 2012, 'Casting out demons in Zimbabwe: A coded political posturing', Exchange 41(4), 352-363. http://dx.doi.org/10.1163/1572543X-12341238

Edwards, D.R., 1992, 'The socio-economic and cultural ethos of the lower Galilee in the first century: Implications for the nascent Jesus movement', in L.I. Levine (ed.), Galilee in late antiquity, pp. 53-73, Harvard University Press, Cambridge, MA.

Fanon, F., 1963, The wretched of the earth, Grove Press, New York, NY.

Foucault, M., 1977, 'Of other spaces, utopias and heterotopias', in N. Leach (ed.), Rethinking architecture: A reader in cultural theory, pp. 330-336, Routledge, New York, NY

Freyne, S., 2000, 'The Galileans in the light of Josephus' life', in Sean Freyne (ed.), Galilee and the Gospels: Collected essays, pp. 27-46, Mohr Siebeck, Tübingen.

Hanson, K.C. \& Oakman, D.E., 1998, Palestine in the time of Jesus: Social structures and social conflicts, Augsburg Fortress Publishers, Winnipeg.

Horsley, R., 1997, The message and the kingdom: How Jesus and Paul ignited a revolution and transformed the ancient world, Grosset/Putnam, New York, NY.

'I resurrected 29 people - Prophet Angel', in Nehanda Radio, 2013, viewed 08 February 2015, from http://nehandaradio.com/2013/09/30/i-resurrected-29people-prophet-angel/

Joshua, T.B., 2014, 'Missing Malaysian Airlines', viewed 08 February 2015, from https://www.youtube.com/watch?v=-Sd5WpNOEvY

Kalu, O.U. (ed.), 2005, African Christianity: An African story, University of Pretoria Press, Pretoria.
Lefebvre, H., 1991, The production of space, Oxford, Blackwell.

Malina, Bruce, 1996, The Social World of Jesus and the Gospels, Routledge, London.

Marcuse, H., 1955, Eros and civilization: A philosophical inquiry into Freud, Boston Press, Beacon, Boston, MA.

Meyers, E., 1981, Archaeology, the rabbis, and early Christianity, Abingdon Press, Nashville, TN.

Muzondidya, J., 2010, 'Makwerekwere: Migration, citizenship and identity among Zimbabweans in South Africa', in J. McGregor (ed.), Zimbabwe's diaspora: Displacement and the cultural politics of survival, pp. 37-58, Berghahn Books, Oxford.

Nietzsche, F., 1967, The will to power, transl. W. Kaufmann, Random House, New York, NY.

Peppard, M., 2010, 'The eagle and the dove: Roman imperial sonship and the baptism of Jesus', New Testament Studies 56, 431-451. http://dx.doi.org/10.1017/ S0028688510000159

Reed, J., 1999, 'Galileans, Israelite Village Communities, and the Sayings of Q', in E. Meyers (ed.), Galilee through the centuries: Confluence of cultures, pp. 89-108, Eisennnbrauns, Winona, MN.

Sartre, J.-P., 1992, Truth and existence, Chicago University Press, Chicago, IL.

Sekum Nhova n.d., The art of clerical charlatanism, viewed 31 March 2014, from http://sekurunhova.realinfozones.com/2014/03/the-art-of-clerical-charlatanismpart-i.html

Shoko, T., 2007, Karanga indigenous religions in Zimbabwe: Health and wellbeing, Hampshire, Ashgate.

Shoko, T., 2013, 'The prophetic figure in Zimbabwean religion', in E. Chitando \& R. Gunda (eds.), Prophets, profit and the Bible in Zimbabwe: Festschrift for Aynos Masocha Moyo, pp. 217-231, Bamberg Press, Bamberg.

Sibiya, P., 2013, 'I am a Christian but Remain Poor; Why? (26 Possible Reasons Why!)', viewed 08 February 2015, from https://www.facebook.com/notes/ apostle-pride-sibiya/i-am-a-christian-but-remain-poor-why26-possiblereasonswhy/4954393796789

Strauss, D.F.,1972, The life of Jesus critically examined, ed. P.C. Hodgson, transl. G. Eliot, Fortress, Philadelphia, PA.

Turner, V. \& Turner, E., 1978, Image and pilgrimage in Christian culture: Anthropological perspectives, Columbia University Press, Oxford.

Van Gennep, A., 1969, The rites of passage, Mouton, Madrid.

Veitch, J., 1960, The rationalists, Doubleday Dolphin Books, New York, NY.

Weber, M., 1930, Protestant ethics and the spirit of capitalism, Routledge, London. 